\title{
Multimodal Image-Guided Enzyme/Prodrug Cancer Therapy
}

Cong Li, Paul T. Winnard Jr., Tomoyo Takagi, Dmitri Artemov and Zaver M. Bhujwalla*

JHU ICMIC Program, The Russell H. Morgan Department of Radiology and Radiological Science, The Johns Hopkins University School of Medicine, Baltimore, MD 21205, USA.

*Correspondence to: Dr. Zaver M. Bhujwalla, JHU ICMIC Program, The Russell H. Morgan Department of Radiology and Radiological Science, Johns Hopkins University School of Medicine, 208C Traylor Building, 720 Rutland Avenue, Baltimore, Maryland 21205, USA. Tel: +1 410-614-2705; Fax: +1 410614-1948; E-mail: zaver@mri.jhu.edu

\section{Supporting Information}

\section{Table of content}

1. Materials and General Experimental Methods. S2-S3

2. Synthesis of DOTA-NHS Ester. S3-S6

3. Isolation of Cytosine Deaminase from Escherichia Coli. S6-S8

4. Synthesis of bCD-PLL Conjugate S8-S11

5. Determination of the MW of bCD-PLL. S11-S12

6. Determination of the Molecular Size of bCD-PLL. S13

7. Determination of the $\left[\mathrm{Gd}^{3+}\right]$ of $\mathrm{Gd}^{3+}$-labeled bCD-PLL. $\quad \mathrm{S} 14$

8. Fluorospectroscopic Studies. $\quad \mathrm{S} 15$

9. Determination of the $r_{1 \mathrm{p}}$ of $\mathrm{Gd}^{3+}$ - bCD-PLL and bCD-PLL. S15-S16

$\begin{array}{ll}\text { 9. Kinetic Studies. S16-S17 } & \text { S18 }\end{array}$

10. Enzymatic Specific Activity Studies S18

11. In vitro Cytotoxicity Studies. S18-S20

12. Cellular uptake in vitro $\quad$ S20-S21

12. Enzymatic Serum Stability Studies. S21

13. In vitro Enzymatic Degradation Studies. S21-S23

14 References. $\quad$ S23 


\section{Materials and General Experimental Methods:}

All organic chemicals and solvents were of analytical grade from Aldrich (St. Louis, MO) and Alfa Aesar (Ward Hill, MA) unless otherwise specified. Poly-L-lysine hydrobromide (56 kDa), phenylmethanesulfonyl fluoride (PMSF), cytosine, uracil, 5-fluorocytosine, 5-fluorouracil, DNaseI and lysozyme were from Sigma (Milwaukee, WI). $N$-[E-maleimidocaproyloxy $]$ sulfosuccinimide (SulfoEMCS), sulfosuccinimidyl-6-(biotin-amido)hexanoate (Sulfo-NHS-LC-Biotin), $N$-succinimidyl Sacetylthiopropionate (SATP), EZ ${ }^{\mathrm{TM}}$ biotin quantitation kit, and Ellman's reagent were from Pierce (Rockford, IL). Rhodamine Red-X succinimidyl ester was from Molecular Probes (Eugene, OR). Fetal bovine serum, penicillin, streptomycin, isopropyl b-D-thiogalactopyranoside (IPTG) and dithiothreitol (DTT) were form Invitrogen (Carlsbad, CA). BD TALON ${ }^{\mathrm{TM}}$ xTractor buffer and BD TALON ${ }^{\mathrm{TM}}$ cobalt affinity resin were from Clontech, (Mountain View, CA). BL21(DE3) E. coli cells, biotinated thrombin, and streptavidin agarose were from Novagen (Madison, WI). Restriction enzymes NdeI, XhoI and ClaI were from New England Biolabs (Ipswich, MA). The MTT cell proliferation kit was from ATCC (Manassas, VA). Amicon ultra-15 centrifugal filter tubes (5,000 and 10,000 MW cutoff) were from Millipore (Bedford, MA). The invasive human mammary epithelial cell lines MDA-MB-231 was obtained from American Type Culture Collection (Rockville, MD). The molecular weight of conjugate was measured from Waters Ultrahydrogel ${ }^{\mathrm{TM}} 500(7.8 \mathrm{~mm} \times 300 \mathrm{~mm})$ gel permeable column, which was operated by High Performance Liquid Chromatography (HPLC) system equipped with a Waters 1525 binary pump and Waters 2487 dual wavelength absorbance detector (Waters Inc. Milford, MA). ${ }^{1} \mathrm{H},{ }^{13} \mathrm{C}$ NMR spectra were recorded at $400 \mathrm{MHz}$ on Varian Mercury400 (Varian Inc. Palo Alto, CA), and chemical shifts were reported in ppm relative to tetramethylsilane. The water proton longitudinal relaxivities $r_{1 \mathrm{p}}$ were determined on a $4.7 \mathrm{~T}$ Omega spectrometer (Bruker Instruments, Fremont, CA) with $15 \mathrm{~cm}$ diameter shielded gradients. Fast Atom Bombardment (FAB) mass spectra and High Resolution 
(HR) FAB mass spectra were obtained on a double sector JEOL JMS-A X505HA mass spectrometer (Peabody, MA). The hydrodynamic radius and molecular size distribution of proteins were measured on a DAWN-EOS Multi-angle light scattering instrument equipped with optilab DSP interferometric refractometer (Wyatt Technology, Santa Barbara, CA). Gadolinium ion concentrations were determined with a TJA High Resolution IRIS inductively coupled plasma and atomic absorption spectrometer (ICPAES) (Thermo Jarrell Ash Corporation, Franklin, MA). Fluorescence spectra were obtained on a Jobin Yvon-Spex ${ }^{\circledR}$ FluoroMax-3 spectrofluorometer (HORIBA Jobin Yvon Inc., Edison, NJ). Wavelength scanning was carried out in increments of $1.0 \mathrm{~nm}$ with 0.1 second integration time, and the slit widths were set to $4.0 \mathrm{~nm} / 4.0 \mathrm{~nm}$ (excitation/emission).

\section{The Synthesis of DOTA-NHS Ester}

DOTA-NHS ester was prepared in our lab with a novel synthetic procedure rather than the purchase (Scheme S1).
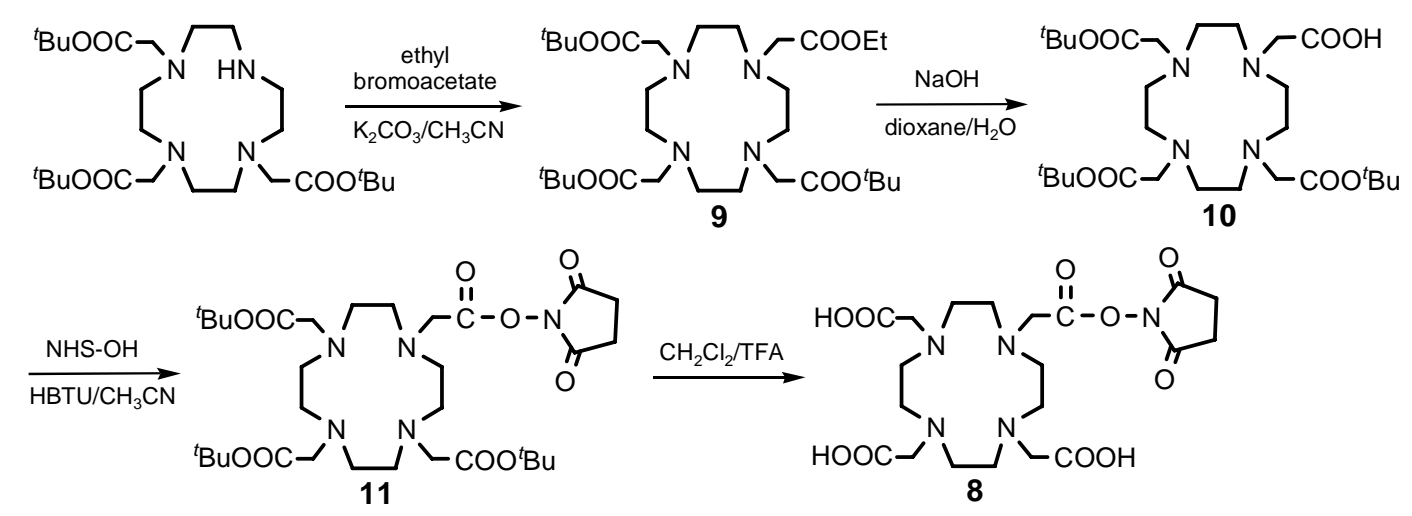

Scheme S1. Synthetic procedure for DOTA-NHS ester from the starting material tris(tertbutoxycarbonylmethyl)-1,4,7,10-tetraazacyclododecane. 
Starting material 1,4,7-tris(tert-butoxycarbonyl-methyl)-1,4,7,10-tetraazacyclodo-decane ${ }^{1} \quad\left(\begin{array}{lll}1.0 & \mathrm{~g}, & 1.9\end{array}\right.$

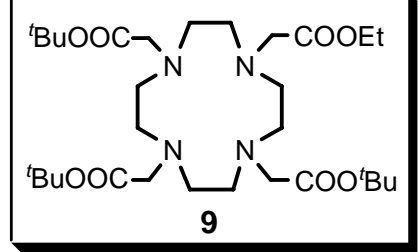

mmol) was dissolved in the mixture of anhydride acetonitrile $(50 \mathrm{~mL})$ and potassium carbonate (540 g, $3.9 \mathrm{mmol}, 2.0$ equiv.). Ethyl bromoacetate (342 g, $2.05 \mathrm{mmol}, 1.05$ equiv.) in $5 \mathrm{~mL}$ acetonitrile was added. This suspension was stirred for about $12 \mathrm{hr}$ under the protection of $\mathrm{N}_{2}$ at $70{ }^{\circ} \mathrm{C}$. After removing the excess $\mathrm{K}_{2} \mathrm{CO}_{3}$ by filtration, acetonitrile was evaporated in vaccu at $40{ }^{\circ} \mathrm{C}$. The light-yellow oil was purified by flash chromatography on silica gel (mobile phase: dichloromethane/methane $=100 / 10$ (v/v)) to give 1-(ethyl acetate)-4,7,10-tris(tert-butoxycarbonylmethyl)-1,4,7,10-tetraazacyclododecane 9 as a light yellow foam $(1.15 \mathrm{~g}, 1.9 \mathrm{mmol})$, yield: $99 \% .{ }^{1} \mathrm{H}$ NMR (400 MHz, $\left.\mathrm{CDCl}_{3}\right): \delta 4.04$ (q, $J=7.4 \mathrm{~Hz}$, $2 \mathrm{H}$ ), 3.78-1.65 (a set of very broad and multiple peaks with an integration corresponding to $24 \mathrm{H}$ ), 1.36 (s, 27H), $1.16(\mathrm{t}, J=7.4 \mathrm{~Hz}, 3 \mathrm{H}) ;{ }^{13} \mathrm{C}$ NMR $\left(100 \mathrm{MHz}, \mathrm{CDCl}_{3}\right): \delta 175.7(\mathrm{C}), 172.4(2 \times \mathrm{C}), 172.2(\mathrm{C}), 82.0$ $(2 \times \mathrm{C}), 81.9(\mathrm{C}), 59.2\left(\mathrm{CH}_{2}\right), 57.4\left(\mathrm{CH}_{2}\right), 56.2\left(2 \times \mathrm{CH}_{2}\right), 55.7\left(\mathrm{CH}_{2}\right), 53.0-50.8\left(4 \times \mathrm{CH}_{2}\right.$, a set of broad peaks), 50.4-47.4 $\left(4 \times \mathrm{CH}_{2}\right.$, a set of broad peaks $), 28.2\left(6 \times \mathrm{CH}_{3}\right), 28.1\left(3 \times \mathrm{CH}_{3}\right), 13.6\left(\mathrm{CH}_{3}\right) ; \mathrm{FAB}^{+}-\mathrm{MS}$ $m / z 623(\mathrm{M}+\mathrm{Na})^{+} ; \mathrm{HRFAB}^{+}-\mathrm{MS}$ Calcd. for $\mathrm{C}_{30} \mathrm{H}_{56} \mathrm{~N}_{4} \mathrm{O}_{8} \mathrm{Na}(\mathrm{M}+\mathrm{Na})^{+}$623.3996, found 623.3986.

Compound 9 (400 mg, $0.67 \mathrm{mmol}$ ) was dissolved in $15 \mathrm{ml}$ of dioxane:0.1 $\mathrm{M} \mathrm{NaOH}$ at 3:1 (v:v). This

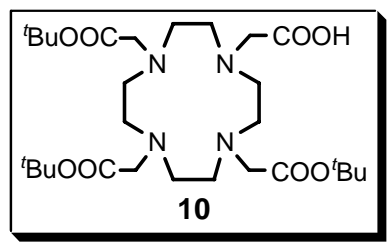
solution was vigorously stirred for about $4 \mathrm{hr}$ under $\mathrm{N}_{2}$ at $50{ }^{\circ} \mathrm{C}$. Dioxane was removed in vaccu at $60{ }^{\circ} \mathrm{C}$, and $20 \mathrm{ml}$ of water was added. After extracting with dichloromethane $(3 \times 30 \mathrm{ml})$, the organic phases were combined and washed with water $(2 \times 20 \mathrm{~mL})$ and brine $(15 \mathrm{~mL})$. After the addition of anhydrous $\mathrm{Na}_{2} \mathrm{SO}_{4}$, dichloromethane was evaporated and a colorless glass-like solid was obtained. This crude material was re-dissolved in $20 \mathrm{~mL}$ anhydride diethyl ether and crystallized by cooling at $4{ }^{\circ} \mathrm{C}$ overnight. The diethyl ether was separated from the resulting white solid through filtration. After drying under vacuum for $2 \mathrm{hr}$, 
the yield of compound 10 was $95 \%$ (364.5 mg, $0.64 \mathrm{mmol}) .{ }^{1} \mathrm{H}$ NMR (400 MHz, $\left.\mathrm{CDCl}_{3}\right): \delta 3.65-1.68$ (a set of very broad and multiple peaks with an integration corresponding to $24 \mathrm{H}), 1.39$ (s, 27H); ${ }^{13} \mathrm{C}$ NMR $\left(100 \mathrm{MHz}, \mathrm{CDCl}_{3}\right): \delta 175.9(\mathrm{C}), 172.4(2 \times \mathrm{C}), 172.1(\mathrm{C}), 82.0(2 \times \mathrm{C}), 81.9(\mathrm{C}), 57.3\left(\mathrm{CH}_{2}\right), 56.3(2 \times$ $\left.\mathrm{CH}_{2}\right), 55.6\left(\mathrm{CH}_{2}\right), 53.2-50.9\left(4 \times \mathrm{CH}_{2}\right.$, a set of broad peaks $), 50.5-47.7\left(4 \times \mathrm{CH}_{2}\right.$, a set of broad peaks $)$, $28.3\left(6 \times \mathrm{CH}_{3}\right), 28.1\left(3 \times \mathrm{CH}_{3}\right) ; \mathrm{FAB}^{+}$-MS m/z $595(\mathrm{M}+\mathrm{Na})^{+}$; HRFAB ${ }^{+}$-MS Calcd. for $\mathrm{C}_{28} \mathrm{H}_{52} \mathrm{~N}_{4} \mathrm{O}_{8} \mathrm{Na}$ $(\mathrm{M}+\mathrm{Na})^{+}$595.3683, found 595.3668.

Compound 10 (200 mg, $0.35 \mathrm{mmol}$ ), $N$-hydroxysuccinimide ( $45.2 \mathrm{mg}, 0.39 \mathrm{mmol}, 1.1$ equiv.), and $O-$

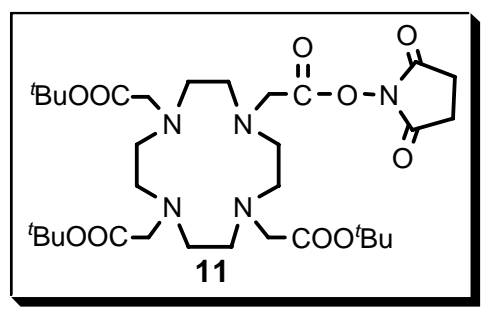
benzotriazol-1-yl- $N, N, N^{\prime}, N^{\prime}$-tetramethyluronium hexafluorophosphate (HBTU) (148 mg, $0.39 \mathrm{mmol}, 1.1$ equiv.) were dissolved in $10 \mathrm{~mL}$ of acetonitrile. The reaction was stirred at room temperature for $24 \mathrm{hr}$. After removing the solvent under the vaccu, the crude product was purified by flash chromatography on silica gel (mobile phase: dichloromethane/methane $=100 / 15(\mathrm{v} / \mathrm{v})$ ) to give compound 11 as a white foam (202 mg, $0.30 \mathrm{mmol})$, yield: $86 \% .{ }^{1} \mathrm{H} \mathrm{NMR}\left(400 \mathrm{MHz}, \mathrm{CDCl}_{3}\right): \delta 3.51-$ $3.04(\mathrm{br}, 4 \mathrm{H}), 3.04-2.70(\mathrm{br}, 8 \mathrm{H}), 2.65-2.02(\mathrm{br}, 16 \mathrm{H}), 1.47$ (s, 27H); ${ }^{13} \mathrm{C} \mathrm{NMR}\left(100 \mathrm{MHz}, \mathrm{CDCl}_{3}\right): \delta$ $173.4(3 \times \mathrm{C}), 173.1(\mathrm{C}), 169.9(2 \times \mathrm{C}), 82.6(3 \times \mathrm{C}), 55.8\left(\mathrm{CH}_{2}\right), 55.7\left(\mathrm{CH}_{2}\right), 54.2\left(2 \times \mathrm{CH}_{2}\right), 53.9(2 \times$ $\left.\mathrm{CH}_{2}\right), 53.7\left(4 \times \mathrm{CH}_{2}\right), 53.4\left(2 \times \mathrm{CH}_{2}\right), 53.2\left(\mathrm{CH}_{2}\right), 53.1\left(\mathrm{CH}_{2}\right), 27.8\left(9 \times \mathrm{CH}_{3}\right) ; \mathrm{FAB}^{+}-\mathrm{MS} \mathrm{m} / \mathrm{z} 692$ $(\mathrm{M}+\mathrm{Na})^{+}$; HRFAB ${ }^{+}$-MS Calcd. for $\mathrm{C}_{32} \mathrm{H}_{55} \mathrm{~N}_{5} \mathrm{O}_{10} \mathrm{Na}(\mathrm{M}+\mathrm{Na})^{+}$692.3847, found 692.3846. 
Compound 11 (200 mg, $0.3 \mathrm{mmol}$ ) was dissolved in $15 \mathrm{ml}$ of dichloromethane:trifluoacetic acid at 1:2

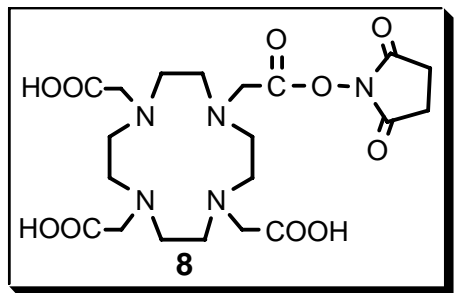

(v:v). This solution was stirred at room temperature for about $5 \mathrm{hr}$. After removing the solvent, the residue was dissolved in $0.5 \mathrm{~mL}$ methanol. Diethyl ether $(10 \mathrm{~mL})$ was added and the final white solid product 8 (138 mg, $0.27 \mathrm{mmol}, 92 \%)$ was obtained. ${ }^{1} \mathrm{H}$ NMR (400 MHz, $\left.\mathrm{CD}_{3} \mathrm{OD}\right): \delta 4.19$ (br, 6H), 3.54 (br, 8H), 3.30 (br, 4H), 3.08 (br, 6H), 2.84 (br, 4H); ${ }^{13} \mathrm{C}$ NMR (100 MHz, $\left.\mathrm{CD}_{3} \mathrm{OD}\right): 175.1$ (3 $\times \mathrm{C}), 173.8(\mathrm{C}), 171.5(2 \times \mathrm{C}), 55.6\left(4 \times \mathrm{CH}_{2}\right), 54.0(2 \times \mathrm{CH}), 53.3\left(4 \times \mathrm{CH}_{2}\right), 52.5\left(4 \times \mathrm{CH}_{2}\right) ; \mathrm{FAB}^{+}-\mathrm{MS}$ $\mathrm{m} / \mathrm{z} 502(\mathrm{M}+\mathrm{H})^{+}$; $\mathrm{HRFAB}^{+}$-MS Calcd. for $\mathrm{C}_{20} \mathrm{H}_{32} \mathrm{O}_{10} \mathrm{~N}_{5}[\mathrm{M}+\mathrm{H}]^{+}, 502.2149$, found 502.2133.

\section{Isolation of Cytosine Deaminase from $E$. Coli}

Routine molecular biology and bacterial protein expression protocols were used to generate pure bacterial cytosine deaminase (bCD) in E. coli. bCD plasmid cloning and expansion was done in BL21(DE3) cells at $37{ }^{\circ} \mathrm{C}$ with LB-ampicillin $(100 \mu \mathrm{g} / \mathrm{mL})$ based selection media. Plasmid preparations from initial transformants were subjected to endonuclease restriction enzyme digests to confirm that selected monoclonal colonies harboured bCD cDNA (Figure S1-A). Protein production was initiated by seeding 4L of LB-AMP media with an aliquot of a $4 \mathrm{~mL}$ overnight culture of BL21(DE3)-pET15b-bCD. At log phase growth $\left(\mathrm{OD}_{600}\right.$ of $\left.0.5-0.6\right)$ protein production was induced by addition of IPTG $(0.5 \mathrm{mM})$, which induces gene expression and increases the yield of the desired protein (Figure S1b). Following $5 \mathrm{~h}$ of 37 ${ }^{\circ} \mathrm{C}$ incubation $\left(\mathrm{OD}_{600}\right.$ in the range of $\left.1.2-1.5\right)$, the cells were harvested by centrifugation at $3000 \mathrm{~g}$ for 20 min at $4{ }^{\circ} \mathrm{C}$, and the cell pellet was re-suspended in BD TALON ${ }^{\mathrm{TM}}$ xTractor buffer plus $5.0 \mathrm{mM}$ imidazole, $0.5 \mathrm{mM}$ PMSF, $0.5 \mathrm{mg} / \mathrm{mL}$ lysozyme, and $2000 \mathrm{U}$ DNaseI. The mixture was incubated and gently shaken at $25^{\circ} \mathrm{C}$ for $20 \mathrm{~min}$, and centrifuged at $20,000 \mathrm{~g}$ for $30 \mathrm{~min}$ at $4{ }^{\circ} \mathrm{C}$. The clear supernatant was collected, and passed through a $0.45 \mu \mathrm{m}$ syringe filter. The filtrate was added to $25 \mathrm{~mL}$ packed bed 
volume of BD TALON ${ }^{\mathrm{TM}}$ resin which was equilibrated with ten bed volumes of equilibration buffer (300 $\mathrm{mM} \mathrm{NaCl}, 20 \mathrm{mM}$ Tris- $\mathrm{HCl} \mathrm{pH}$ 7.0, $5 \mathrm{mM}$ imidazole, $0.5 \mathrm{mM}$ PMSF). The affinity resin was washed three times with ten bed volumes of washing buffer $(300 \mathrm{mM} \mathrm{NaCl}, 20 \mathrm{mM}$ Tris- $\mathrm{HCl} \mathrm{pH}$ 7.0, $10 \mathrm{mM}$ imidazole, $0.5 \mathrm{mM}$ PMSF), and histidine-tagged-bCD (His-bCD) protein was eluted from the resin with five bed volumes of elution buffer $(300 \mathrm{mM} \mathrm{NaCl}, 20 \mathrm{mM}$ Tris- $\mathrm{HCl} \mathrm{pH}$ 7.0, $150 \mathrm{mM}$ imidazole, $0.5 \mathrm{mM}$ PMSF). The eluted fractions were concentrated by centrifugal filtration in a $15 \mathrm{~mL}, 10,000 \mathrm{MW}$ cut off tube at $4000 \mathrm{~g}$ and stored at $-20{ }^{\circ} \mathrm{C}$ in storage buffer $(100 \mathrm{mM} \mathrm{NaCl}, 20 \mathrm{mM}$ Tris- $\mathrm{HCl} \mathrm{pH}$ 8.0, $1.0 \mathrm{mM}$ EDTA, 1.0 mM DTT, 50\% glycerol). Purified His-tagged-bCD (His-bCD) was analyzed by SDS-PAGE and on a HPLC size-exclusion column, which indicated a purity of above $97 \%$, and was thus used without further purification (Figure S1-B). The protein concentration was determined by measuring the absorbance of bCD (monomer $\varepsilon_{279}=76 \mathrm{mM}^{-1} \mathrm{~cm}^{-1}$ ). Typically, $60-80 \mathrm{mg}$ of pure His-bCD was obtained per liter of bacterial culture media. Thrombin cleavage of the $N$-terminatal histidine tag was then undertaken. DTT in the storage buffer was removed from the protein by centrifugal filtration $(10,000$ MW cut off) as described above. His-bCD (100 mg) was transferred to $50 \mathrm{~mL}$ of $1 \mathrm{X}$ cleavage buffer (20 $\mathrm{mM}$ Tris- $\mathrm{HCl} \mathrm{pH} 8.4,150 \mathrm{mM} \mathrm{NaCl}, 2.5 \mathrm{mM} \mathrm{CaCl}_{2}$ ) and $50 \mathrm{U}$ biotinated thrombin was added. After incubation at $37^{\circ} \mathrm{C}$ for $3 \mathrm{hr}, 800 \mu \mathrm{L}$ streptavidin agarose slurry was added and incubated at $25^{\circ} \mathrm{C}$ for half hour with rocking at $10 \mathrm{rev} / \mathrm{min}$. The agarose beads were sedimented by centrifuging at $500 \mathrm{~g}$, the supernatant was concentrated, and analyzed by SDS-PAGE (Figure S1-C). The resulting bCD (40-60 $\mathrm{mg} / \mathrm{ml}$ ) was transferred into storage buffer by centrifugal filtration and stored at $-20^{\circ} \mathrm{C}$. 

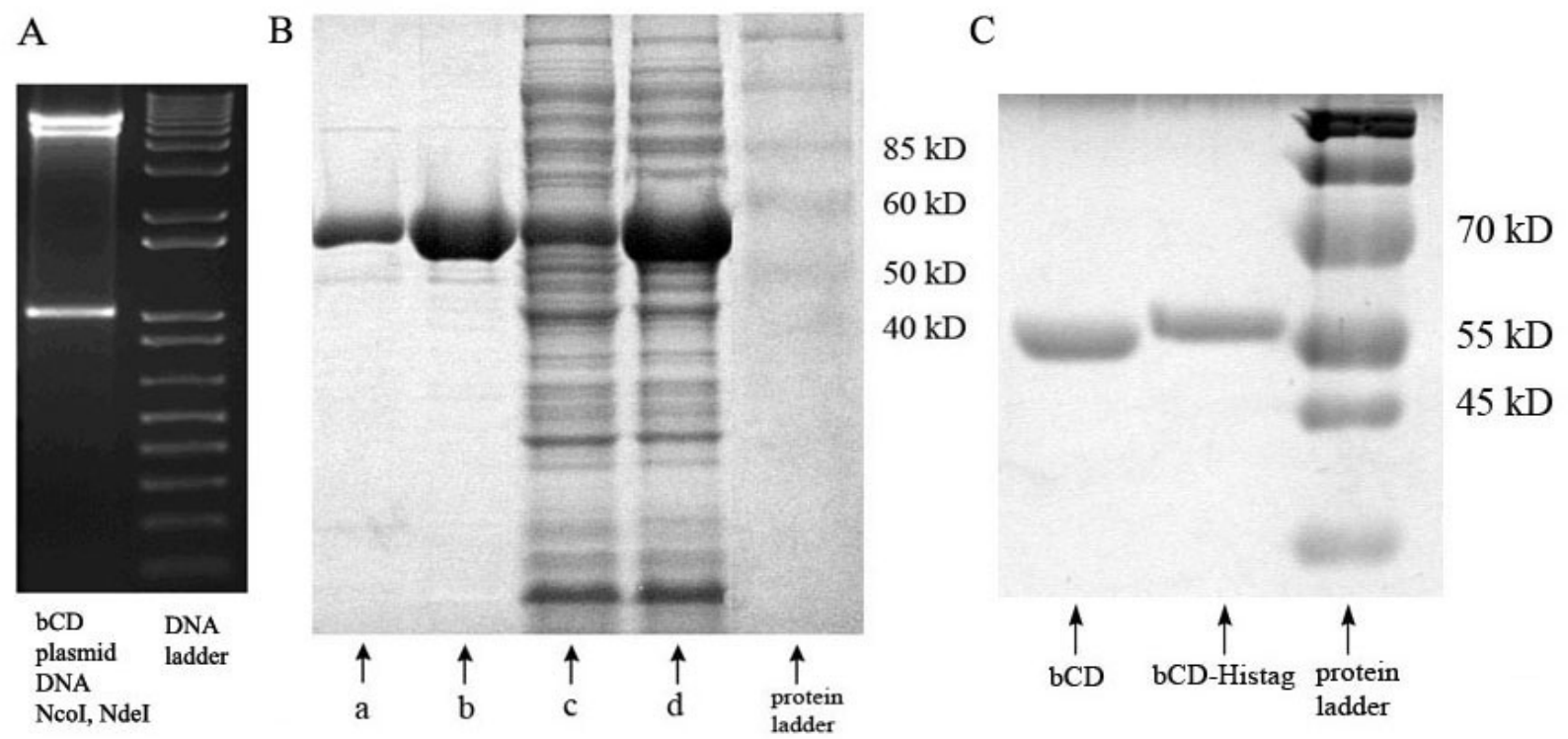

Figure S1. Quality control of bCD protein production. (A) Agarose gel electrophoresis showing the release of bCD coding sequence ( $\sim 1000 \mathrm{bp}$ fragment) from pET15b-bCD plasmid after digestion with Nco I and Nde I restriction endonucleases. (B) Denaturing SDS-PAGE of the proteins before and after purification through the cobalt affinity column. Lanes a (no ITPG induction) and $\mathbf{b}$ (ITPG induction) show protein patterns of equal volumes of affinity column purified His-bCD. It is evident that ITPG induction increases protein production considerably. Lanes c (no ITPG induction) and d (ITPG induction) show the corresponding total cell lysate protein patterns. In both cases it is evident that the single affinity column purification step provides highly purified $b C D$ from a highly complex mixture of proteins. (C) Denaturing SDS-PAGE of the bCD before and after the thrombin cleavage of the His-tag.

\section{Synthesis of bCD-PLL conjugate}

Biotin-rhodamine red conjugated PLL (2). Rhodamine $\mathrm{Red}^{\mathrm{TM}}-\mathrm{X}$ succinimidyl ester (5-isomers) (11 mg,

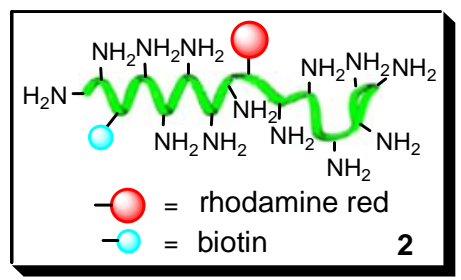

$1.43 \times 10^{-5} \mathrm{~mol}, 4.0$ equiv.) in $1.0 \mathrm{~mL}$ anhydrous $\mathrm{DMF}$ was added dropwise to PLL (20 mg, $\left.3.57 \times 10^{-6} \mathrm{~mol}\right)$ dissolved in $4 \mathrm{~mL} 0.1 \mathrm{M}$ HEPES buffer $\mathrm{pH}$ $=8.3$. After stirring at $25^{\circ} \mathrm{C}$ for one hour, the mixture was loaded to centrifugal filter tube (MW 5000 cut off). The hydrolytic products and other small molecular byproducts were removed by adding $4 \times 15 \mathrm{~mL} 0.1 \mathrm{M}$ HEPES $\mathrm{pH} 7.4$ during the centrifugal process at $4000 \mathrm{rpm}$. The purified rhodamine conjugated PLL was concentrated as a deep red clear solution in $2 \mathrm{~mL}$ 0.1 HEPES buffer $\mathrm{pH}$ 7.4. The degree of the rhodamine labeling was determined by 
measuring the absorbance of the PLL $\left(\varepsilon_{213}=46,800 \mathrm{M}^{-1} \mathrm{~cm}^{-1}\right)$ and the absorbance of the rhodamine $\left(\varepsilon_{572}=\right.$ 120,000 $\mathrm{M}^{-1} \mathrm{~cm}^{-1}$ ). On average, 0.8 rhodamine moieties per PLL molecule was obtained. The functionalization of biotin to PLL was also prepared according to the manufacturer's protocol. Rhodamine conjugated PLL $\left(3.40 \times 10^{-6} \mathrm{~mol}, 0.85 \mathrm{mM}\right)$ in $4 \mathrm{~mL} 0.1$ M HEPES buffer $\mathrm{pH} 8.3$ was treated with sulfoNHS-LC-biotin ( $15 \mathrm{mg}, 2.7 \times 10^{-5} \mathrm{~mol}, 8$ equiv.) dissolved in $0.5 \mathrm{~mL}$ anhydrous DMF. The mixture was allowed to stir at r.t. for $1.5 \mathrm{hr}$, and purified into $0.1 \mathrm{M}$ HEPES pH 7.4 by centrifugal filtration (5000 MW cut off) as described above. The concentration of purified product 2 as a deep red solution was determined from the rhodamine $\left(\varepsilon_{572}=120,000 \mathrm{M}^{-1} \mathrm{~cm}^{-1}\right)$. The biotination labeling degree was measured by using the EZ $^{\mathrm{TM}}$ biotin quantitation kit (catalog number: 28005, Pierce, Rockford, IL). Briefly, the absorbance of HAHB/Avidin in PBS at $500 \mathrm{~nm}$ was measured before and after the addition of compound 2 with the concentration of $30 \mathrm{uM}$ (based on PLL). From the extinction coefficiency of HAHB/Avidin complex, the biotin concentration can be calculated. The biotination degree was obtained as 3.0 biotins per PLL molecule, and the yield of compound $\mathbf{2}$ is $92 \%$ (based on PLL).

Biotin-rhodamine-DOTA conjugated polylysine (3). The conjugation of DOTA chelate to PLL was

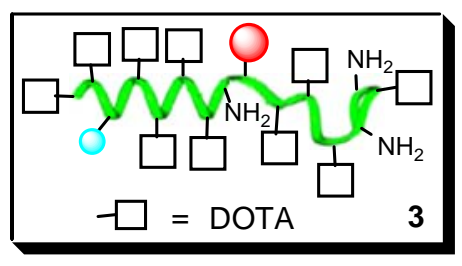

similar to previous synthetic steps. To the solution of compound 2 (3.30 $\times 10^{-6} \mathrm{~mol}, 1.67 \mathrm{mM}$, based on PLL) in $2 \mathrm{~mL} 0.3 \mathrm{M}$ HEPES buffer $\mathrm{pH} 8.8$, DOTA-NHS ester (330 mg, $6.6 \times 10^{-4} \mathrm{~mol}, 200$ equiv.) dissolved in $1.0 \mathrm{~mL}$ anhydrous DMF was added with three potions. $1.0 \mathrm{M} \mathrm{NaOH}$ solution was added during the reaction process to maintain the $\mathrm{pH}$ value around 8.8 . The mixture was stirred at r.t. for further $3 \mathrm{~h}$, and the DOTA modified conjugate 3 was purified into 0.1 M HEPES pH 7.4 by the centrifugal filtration (MW 5000 cut off) as described above with the yield of 92\% (based on PLL). 
Biotin-rhodamine-Gd ${ }^{3+}$-DOTA conjugated polylysine (4). The complexation of DOTA-PLL conjugate

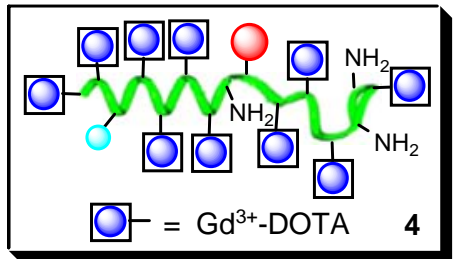
with gadolinium ions was conducted as previous reported. ${ }^{2} \mathrm{Gd}_{2}\left(\mathrm{CO}_{3}\right)_{3}(148$ $\mathrm{mg}, 3.0 \times 10^{-4} \mathrm{~mol}, 100$ equiv. $)$ was added to the compound $3\left(3.0 \times 10^{-6} \mathrm{~mol}\right.$, $0.3 \mathrm{mM}$, based on PLL) in $10 \mathrm{~mL} 0.1 \mathrm{M}$ HEPES $\mathrm{pH}$ 7.4. The suspension was allowed to stir at $60{ }^{\circ} \mathrm{C}$ for $12 \mathrm{hr}$. The excess $\mathrm{Gd}_{2}\left(\mathrm{CO}_{3}\right)_{3}$ was spin down by the centrifuging (2000 rpm), and the clear supernetant was purified into PBS pH 7.4 by the centrifugal filtration (MW 5000 cut off) as described above with a yield of 97\% (based on PLL).

Maleimide-biotin-rhodamine-Gd ${ }^{3+}$-DOTA conjugated polylysine (5). $N$-( $\varepsilon$-maleimidocapro-

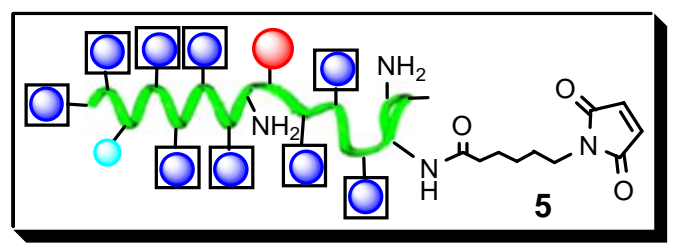
yloxy)sulfosuccinimide ester (Sulfo-EMCS) $(11.9 \mathrm{mg}, 2.9 \times$ $10^{-5}$ mol, 10 equiv.) dissolved in $200 \mathrm{uL}$ DMF was added dropwise to the solution of compound $4\left(2.9 \times 10^{-6} \mathrm{~mol}, 14.5\right.$ $\mathrm{mM}$ ) in $2 \mathrm{~mL} \mathrm{PBS} \mathrm{pH} \mathrm{7.4.} \mathrm{After} \mathrm{stirring} \mathrm{at} \mathrm{r.t.} \mathrm{for} 2 \mathrm{~h}$, the mixture was purified into PBS $\mathrm{pH} 7.0$ by centrifugal filtration (MW 5000 cut off) and concentrated to $1 \mathrm{~mL}$ with a yield of $95 \%$ (based on PLL).

Sulfhydryl modified bCD (6). $N$-succinimidyl S-acetylthiopropionate (SATP) $\left(5.0 \mathrm{mg}, 2.0 \times 10^{-5} \mathrm{~mol}\right)$

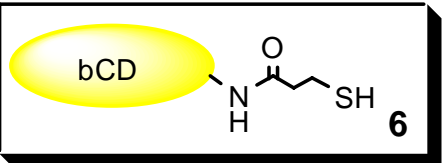
was dissolved in $500 \mathrm{uL}$ anhydrous DMF. Immediately, $130 \mathrm{uL}$ SATP solution $\left(5.15 \times 10^{-6} \mathrm{~mol}, 7.0\right.$ equiv. $)$ was added to the solution of bacterial cytosine deaminase $(\mathrm{bCD})$ in $3.0 \mathrm{~mL} \mathrm{PBS} \mathrm{pH}=7.4\left(220 \mathrm{mg}, 7.37 \times 10^{-7}\right.$ mol, $244 \mathrm{uM}$ ). The mixture was rocked gently for $1 \mathrm{~h}$, then purified and concentrated into $1.0 \mathrm{~mL}$ PBS pH 7.4 by centrifugal filtration (MW 10,000 cut off) as described above. The purified S-acetylthioacetate modified product was concentrated to $1.0 \mathrm{~mL}$ PBS buffer $\mathrm{pH} 7.4$, and combined with $100 \mathrm{uL}$ deacetylation solution (0.5 M hydroxylamine, $25 \mathrm{mM}$ EDTA in PBS, $\mathrm{pH}$ 7.4). After incubation for 2 hours 
at r.t., the mixture was purified into $10 \mathrm{mM}$ EDTA in PBS pH 7.0 by centrifugal filteration (MW 10,000 cut off) to minimize the formation of disulfide bond. The yield of compound 6 was calculated as $94 \%$ by measuring the absorbance of $\mathrm{bCD}\left(\varepsilon_{279}=76 \mathrm{mM}^{-1} \mathrm{~cm}^{-1}\right)$. The determination of degree of sulfhydrylation on the protein was conducted by using Ellman's reagent. Briefly, $250 \mathrm{uL}$ of compound 6 with a concentration less than $0.1 \mathrm{mM}(30 \mathrm{mg} / \mathrm{mL})$ was added to the mixture of $2.5 \mathrm{~mL}$ reaction buffer (PBS, $\mathrm{pH}$ 8.0, $1 \mathrm{mM}$ EDTA) and $50 \mathrm{uL}$ Ellman's reagent solution $(4.0 \mathrm{mg} / \mathrm{mL})$. After incubating for $15 \mathrm{~min}$, the absorbance of the sample at $412 \mathrm{~nm}$ was read. The concentration of sulfhydryls can be calculated from the absorbance of the product TNB $\left(\varepsilon_{412}=714,150 \mathrm{M}^{-1} \mathrm{~cm}^{-1}\right)$. Averagely, 1.3 sulfhydryl groups were functionalized on each bCD hexamer.

bCD-PLL conjugate (1). 1.2 equivalent of maleimide functionalized PLL $5\left(8.3 \times 10^{-7} \mathrm{~mol}, 416 \mathrm{uM}\right)$ in 2

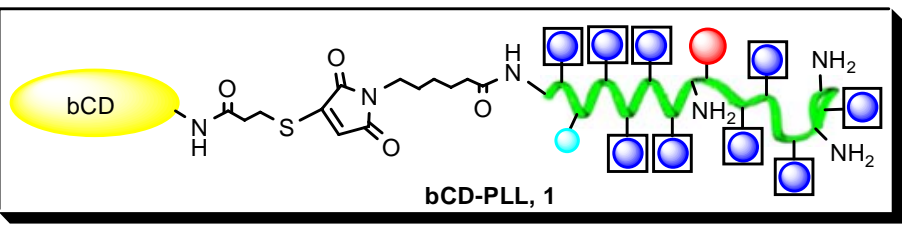
mL PBS 7.0 was mixed with the sulfhydryl modified bCD $6\left(6.93 \times 10^{-7} \mathrm{~mol}, 693 \mathrm{uM}\right)$ in 1 $\mathrm{mL}$ PBS $\mathrm{pH}$ 7.0. After incubation for $1 \mathrm{hr}$ at r.t., the mixture was purified into PBS pH 7.4 by centrifugal filtration (MW 10,000 cut off). The yield of compound 7 was about $95 \%$ (based on bCD) by measuring the absorbance of bCD at $279 \mathrm{~nm}$. The conjugation degree between PLL and bCD (hexamer) was determined as 1.1 by recording the absorbance of bCD $\left(\varepsilon_{279}=76 \mathrm{mM}^{-1} \mathrm{~cm}^{-1}\right)$ and the absorbance of rhodamine $\left(\varepsilon_{572}=120,000 \mathrm{M}^{-1} \mathrm{~cm}^{-1}\right)$.

\section{Determination of Molecular Weight of bCD-PLL by Gel Permeation Chromatography}

All the size exclusion chromatographic (SEC) studies were carried out as the below typical method if there is not any specific mention. Mobile phase: $0.1 \mathrm{X} \mathrm{PBS}, \mathrm{pH} 7.4$; isocratic flow rate: $0.7 \mathrm{~mL} / \mathrm{min}$; operating temperature: $25{ }^{\circ} \mathrm{C}$; injected volume: $20 \mu \mathrm{L}$. The effluent peak of bCD was monitored at 280 
$\mathrm{nm}$, whereas bCD-PLL was monitored at 280 and $570 \mathrm{~nm}$ respectively. The gel-permeable column was calibrated by the Gel Filtration Molecular Weight Kit (Aldrich, St. Louis, MO), which comprises a set of protein markers in the range of $29 \mathrm{kDa}$ to $669 \mathrm{kDa}$. The void volume $\left(\mathrm{V}_{\mathrm{o}}\right)$ of the column is determined by applying the blue dextran at a concentration of $2 \mathrm{mg} / \mathrm{mL}$. The leading peak monitored at $280 \mathrm{~nm}$ indicates the void volume. The elution volumes $\left(\mathrm{V}_{\mathrm{e}}\right)$ of the different protein standards with the injection concentration $5.0 \mathrm{mg} / \mathrm{mL}$ were measured with the same HPLC method. The molecular weight calibration curve was obtained by plotting molecular weight vs. $\mathrm{V}_{\mathrm{e}} / \mathrm{V}_{\mathrm{o}}$ of each protein standard (Figure S2-B). The elution volumes $\left(\mathrm{V}_{\mathrm{e}}\right)$ of $\mathrm{bCD}$ and bCD-PLL were measured with the same method. The effluent peak of bCD was detected at $280 \mathrm{~nm}$, while the effluent peak of bCD-PLL was detected at 280 and $570 \mathrm{~nm}$ in separated experiments (Figure S2-A). The molecular weights of bCD and bCD-PPL were obtained as 302 $\mathrm{kD}$ and $345 \mathrm{kD}$ respectively by applying their $\mathrm{V}_{\mathrm{e}} / \mathrm{V}_{\mathrm{o}}$ values against the calibration curve (Figure $\mathrm{S} 2-\mathrm{B}$ ).
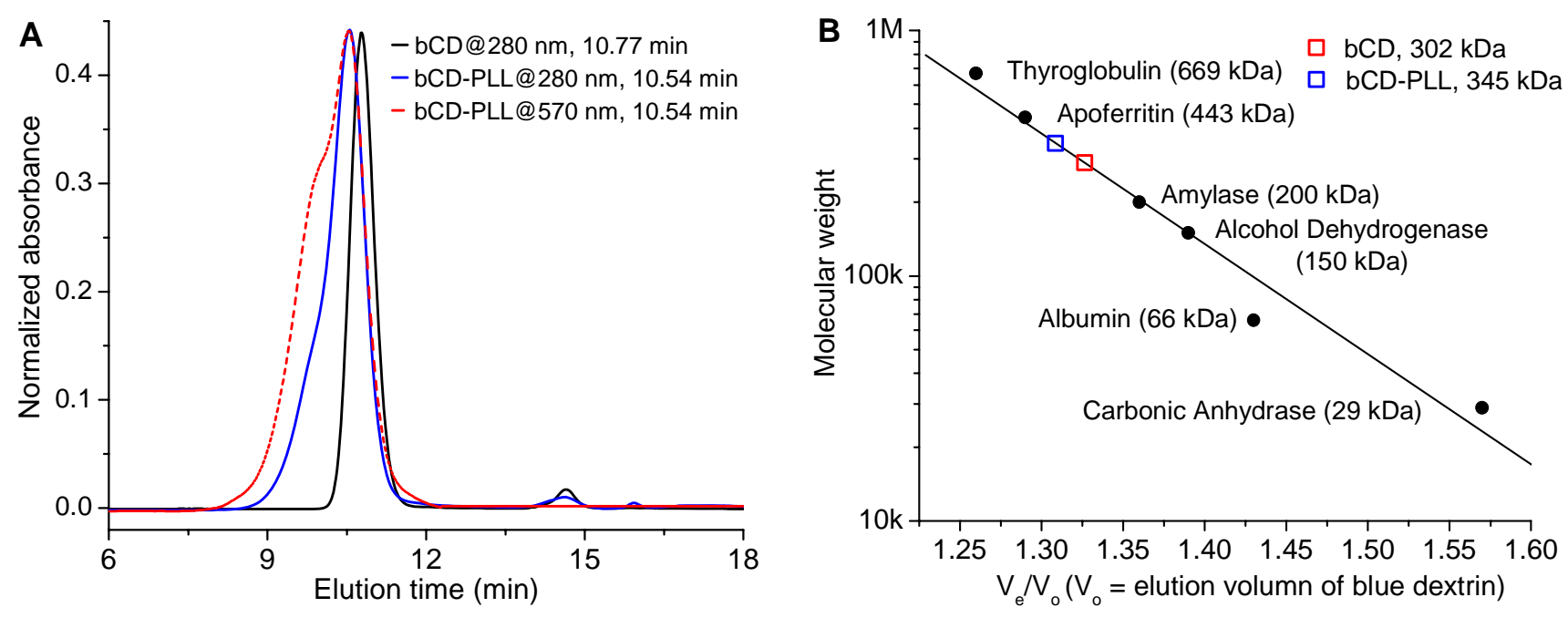

Figure S2. Determination of the molecular weight of bCD and bCD-PLL conjugate. (A) Gel permeable chromatography of bCD monitored at $280 \mathrm{~nm}$ (black line), and bCD-PLL monitored at 280 (blue line) and $570 \mathrm{~nm}$ (red dot line). (B) The determination of the molecular weight of bCD and bCD-PLL with the reference of the calibration line, which was fitted by measuring different protein markers (molecular weight ranged from 29-669 $\mathrm{kDa}$ ) with the same HPLC method. 


\section{Determination of Hydrodynamic Radius and Size Distribution of bCD-PLL by Dynamic Light}

\section{Scattering (DLS)}

Hydrodynamic radius of bCD-PLL and bCD was determined by dynamic light scattering (DLS) DynaPro instrument (Wyatt Technology, CA). The measurements were performed at room temperature using a 20 sec acquisition time. The standard solution of bovine serum albumin (BSA) in distilled water with concentration $2.0 \mathrm{mg} / \mathrm{ml}$ was used for the calibration of the instrument. Prior measurement, the laser power was adjusted to keep the intensity between 500,000 and 150,000,000 counts. The samples were filtered through $0.45 \mu \mathrm{m}$ filter and diluted to $1.0 \mathrm{mg} / \mathrm{mL}$ by PBS $\mathrm{pH} 7.4$. The hydrodynamic radius and the size distribution were calculated with the regularization algorithm provided by DYNAMICS software. Figure S3 shows hydrodynamic radius and size distribution of bCD-PLL and bCD.
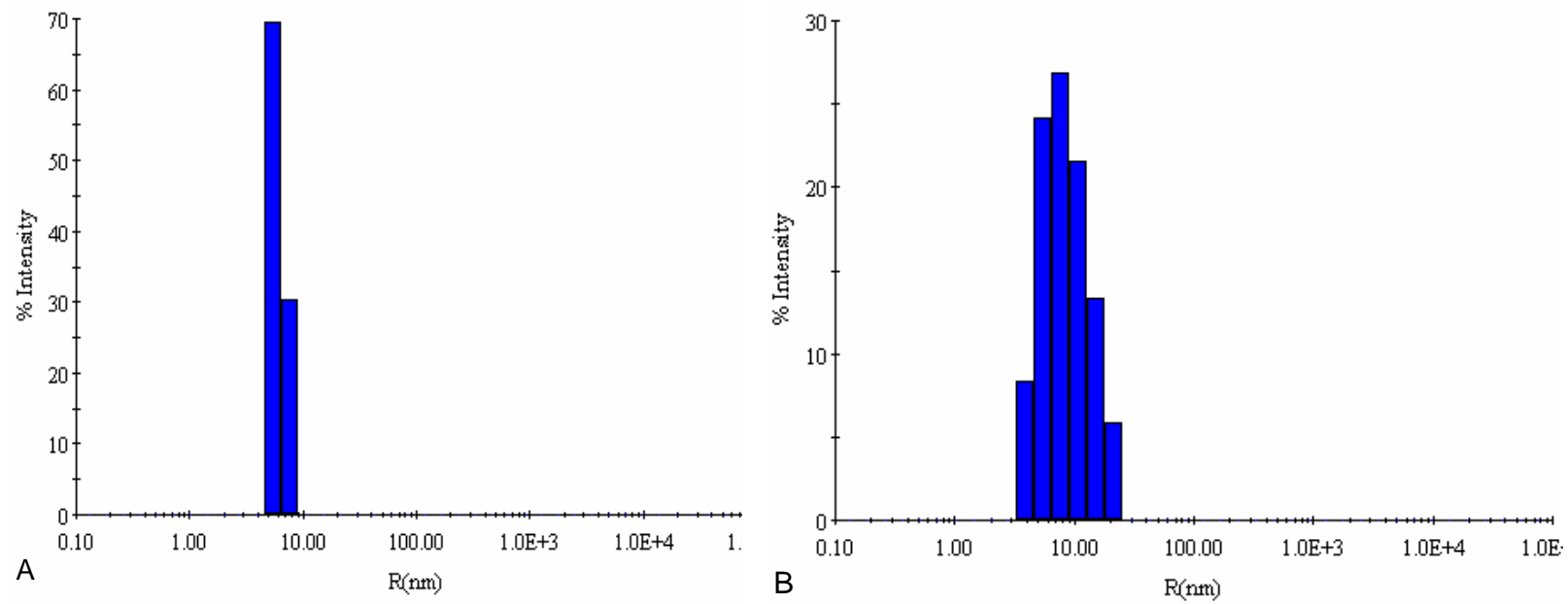

Figure S3. Hydrodynamic radius and size distribution of bCD (A) and bCD-PLL (B) measured by dynamic light scattering. 


\section{Determination of $\mathrm{Gd}^{3+}$ Concentration in Compound 4}

$\mathrm{Gd}^{3+}$ concentration of biotin-rhodamine-Gd ${ }^{3+}$-DOTA conjugated PLL 4 was determined by TJA High Resolution IRIS model ICP-AES (Inductively Coupled Plasma Atomic Emission Spectrometry) with RF power at $1100 \mathrm{~W}$ and nebulizer gas flow at $0.9 \mathrm{~L} / \mathrm{min}$. The standard solutions with the $\mathrm{Gd}^{3+}$ concentration of $1,5,10,20,50,100,200 \mathrm{ppm}$ in $3 \%$ nitric acid were prepared, and a calibration curve was made by plotting the corresponding chromatographic peaks vs. the $\mathrm{Gd}^{3+}$ concentrations. Stock solution of compound $4(0.83 \mathrm{mM})$ was diluted 100 times by $3 \%$ nitric acid. The $\mathrm{Gd}^{3+}$ concentration of the sample was obtained by applying the detected $\mathrm{Gd}^{3+}$ peak against the calibration curve (Figure S4).

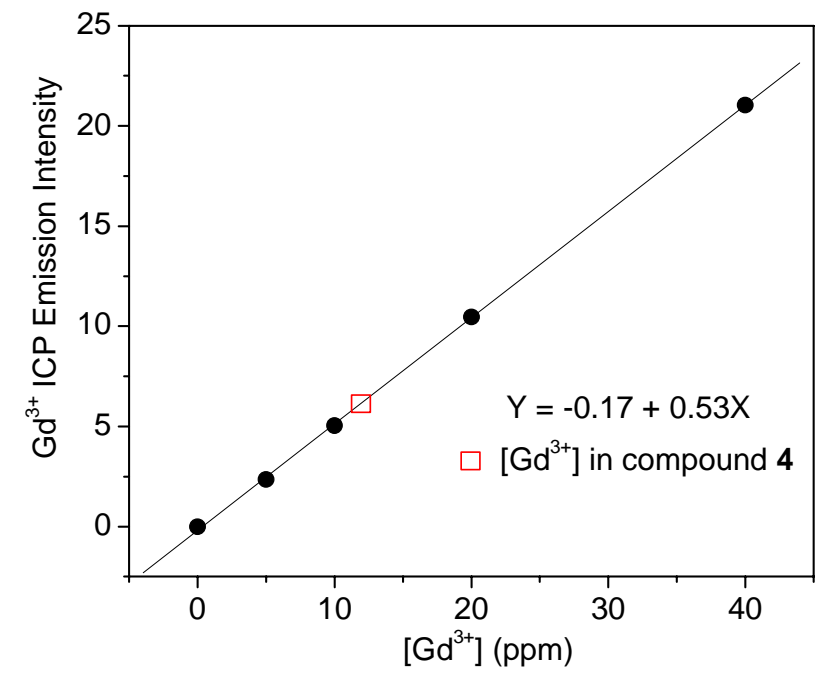

Figure S4. Determination of the $\mathrm{Gd}^{3+}$ concentration in compound 4 . The calibration curve was prepared by plotting ICP emission intensity of $\mathrm{Gd}^{3+}$ against the standard solutions with known $\mathrm{Gd}^{3+}$ concentrations. 


\section{Fluorospectroscopic Studies}

Two micro-liters of bCD-PLL $(77.4 \mu \mathrm{M})$ in PBS or rhodamine red-X succinimidyl ester $(70 \mu \mathrm{M})$ in DMSO were diluted to $1 \mathrm{~mL}$ in PBS pH 7.4 in quartz cuvettes. Fluorescent spectra were recorded upon excitation at $572 \mathrm{~nm}$ and normalized to the same maximal intensity (Figure S5).

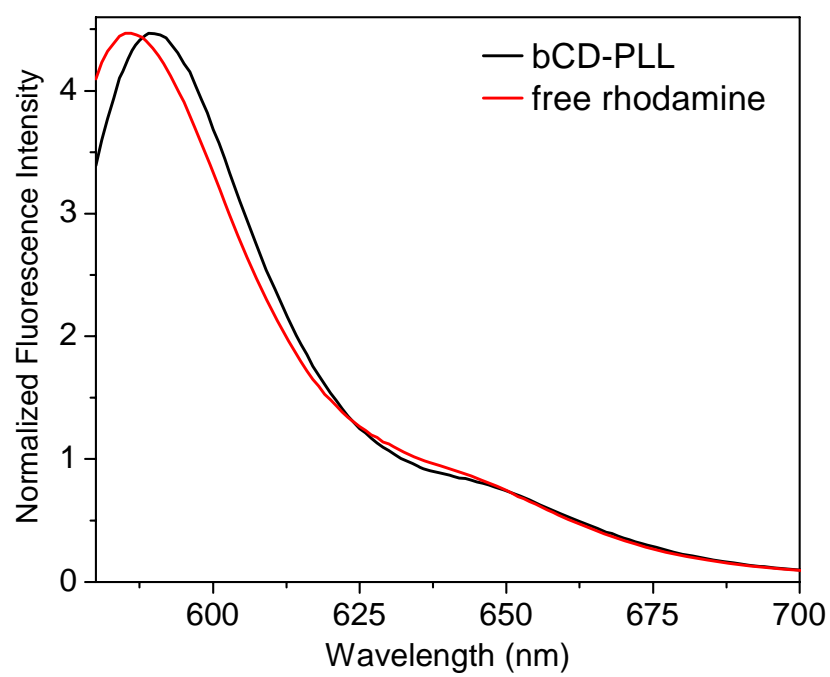

Figure S5. Normalized fluorescence spectra of free rhodamine and bCD-PLL 1 in PBS (excited at 572 $\mathrm{nm})(\mathrm{pH}$ 7.4). Red line: emission of free rhodamine centered at $586 \mathrm{~nm}$; black line: emission spectra of bCD-PLL 1 centered at $590 \mathrm{~nm}$.

\section{Determination of ${ }^{1} \mathrm{H}$ Longitudinal Relaxivity $\boldsymbol{r}_{1 \mathrm{p}}$ of 4 and bCD-PLL.}

Water proton longitudinal relaxivity, $r_{1}$, of compound 4 and bCD-PLL 1 were determined on a $4.7 \mathrm{~T}$ Omega spectrometer (Bruker Instruments, Fremont, CA) with $15 \mathrm{~cm}$ diameter shielded gradients at $25{ }^{\circ} \mathrm{C}$. An inversion recovery sequence was used with 9 different recovery times $(5,10,20,40,60,80,100,200$, $400 \mathrm{~ms}$ ). A nonlinear fitting algorithm was used to fit the observed MR amplitudes to the exponential recovery function to give the $\mathrm{T}_{1}$ relaxation time for each particular sample. Four concentrations were used to determine the $r_{1}$ value by plotting the reciprocals of $\mathrm{T}_{1}$ against the concentration of the $\mathrm{Gd}^{3+}$ ions (Figure S6). 

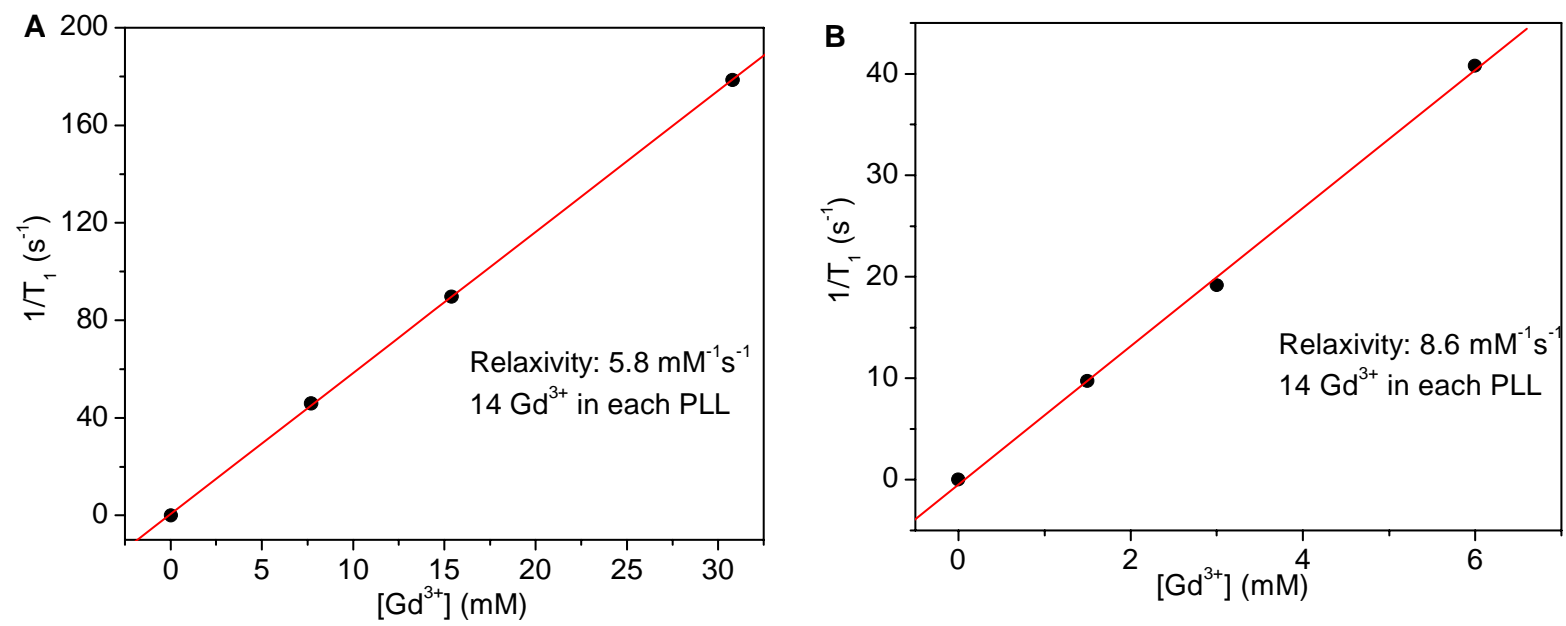

Figure S6. The ${ }^{1} \mathrm{H}$ longitudinal relaxivity of $\mathrm{Gd}^{3+}$-DOTA conjugated PLL 4 (A) and bCD-PLL 1 (B) were determined by plotting the $1 / \mathrm{T}_{1}$ vs. the concentration of $\mathrm{Gd}^{3+}$ at $4.7 \mathrm{~T}, \mathrm{pH} 7.4,25{ }^{\circ} \mathrm{C}$. $\left[\mathrm{Gd}^{3+}\right]$ in compound 4 was measured from the ICP-AES. $\left[\mathrm{Gd}^{3+}\right]$ in bCD-PLL was calculated from the concentration of $b C D$ hexamer. The ratio of $b C D$ hexamer $/\left[\mathrm{Gd}^{3+}\right]$ was found to be $1 / 14$.

\section{Kinetic Studies}

Enzyme assays with cytosine as the substrate were performed according to the reported method. ${ }^{3}$ Kinetic values of bCD-PLL 1 relative to bCD were obtained by measuring the time-dependent absorbance of cytosine at $286 \mathrm{~nm}$. Reaction solutions with the cytosine concentrations of $0.05,0.1,0.2,0.4,0.5,0.6,0.8$, $1.0 \mathrm{mM}$ were prepared in $50 \mathrm{mM}$ Tris- $\mathrm{HCl} \mathrm{pH} \mathrm{7.5.} \mathrm{After} \mathrm{adding} \mathrm{the} \mathrm{enzyme,} \mathrm{the} \mathrm{absorbance} \mathrm{at} 286 \mathrm{~nm}$ were recorded immediately at every $15 \mathrm{~s}$ for a total $5 \mathrm{~min}$ at $25^{\circ} \mathrm{C}$. The initial velocity of enzyme to catalyze cytosine at corresponding concentration can be calculated from the absorbance decrease at 286 $\mathrm{nm}\left(\Delta \varepsilon_{286}=-0.68 \mathrm{mM}^{-1} \mathrm{~cm}^{-1}\right)$. These measurements were repeated 3-4 times by using the same amount of enzyme for each cytosine concentration. Woolf plots were used to determine Michealis-Menton contant $K_{\mathrm{m}}$ and turn over number, $k_{\mathrm{cat}},\left(k_{\mathrm{cat}}=V_{\mathrm{max}} /[E]\right.$, where $V_{\max }$ is the maximal catalytic velocity; [E] is the total enzyme concentration) of bCD-PLL (Figure S7). Similar enzyme assays with 5-FC as the substrate were performed according to Black et al. ${ }^{4}$ Reaction solutions ( $2 \mathrm{~mL}$ ) containing $0.4,0.8,1.6,3.2,4.8,6.4$, or 
9.6 mM 5-FC in $50 \mathrm{mM}$ Tris- $\mathrm{HCl} \mathrm{pH} 7.5$ were incubated with bCD-PLL at $25^{\circ} \mathrm{C}$ separately. Aliquots $(50$ $\mathrm{uL}$ ) of the reaction solution were taken every $90 \mathrm{~s}$ over a $15 \mathrm{~min}$ period, and immediately quenched in $1.95 \mathrm{~mL} 0.1 \mathrm{M} \mathrm{HCl}$. Initial catalytic velocity corresponding concentration can be calculated from the absorbance decrease at $297 \mathrm{mn}\left(\Delta \varepsilon_{297}=-0.41 \mathrm{mM}^{-1} \mathrm{~cm}^{-1}\right)$. Assays were repeated 3-4 times by using the same amount of enzyme for each $5 \mathrm{FC}$ concentrations. The kinetic parameters as $K_{\mathrm{m}}$ and $k_{\text {cat }}$ were determined as the same way as the cytosine.
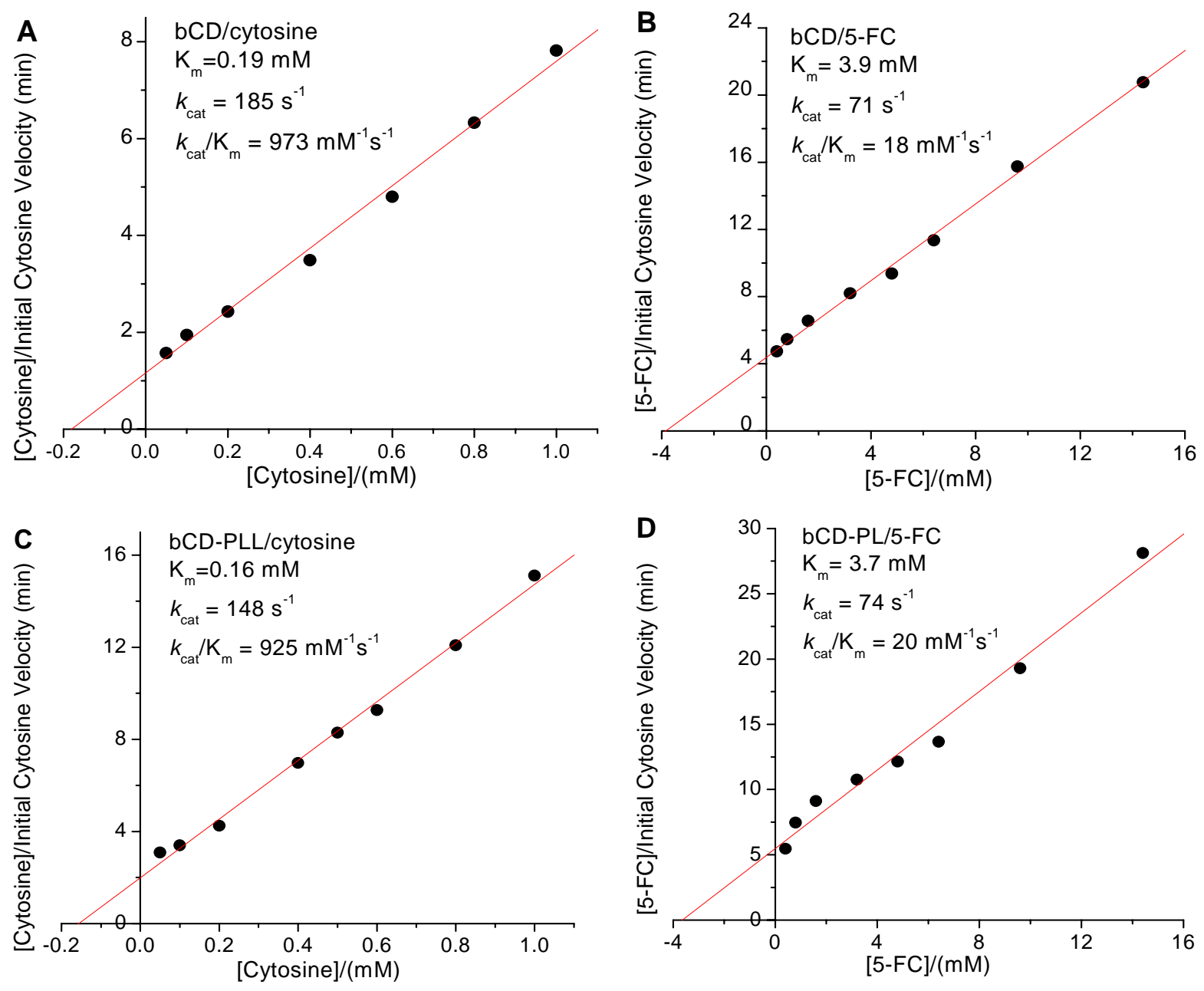

Figure S7. Kinetic parameters obtained from the woolf plot by plotting the value of [substrate] $/ v$ vs. the [substrate], where $v$ is the initial catalytic velocity at the corresponding substrate concentration. $-K_{\mathrm{m}}=$ intercept at X-axis, $V_{\max }=K_{\mathrm{m}} /$ intercept at Y-axis, $K_{\text {cat }}=V_{\max } /[$ enzyme $]$. Each data point represents the average of 3-4 measurements. 


\section{Enzymatic Specific Activity}

Enzyme $(0.5-2.0 \mu \mathrm{g})$ was added to a $0.5 \mathrm{mM}$ cytosine solution prepared in $50 \mathrm{mM}$ Tris- $\mathrm{HCl} \mathrm{pH} 7.5$ at 25

${ }^{\circ} \mathrm{C}$. Absorbance readings at $286 \mathrm{~nm}$ were taken immediately upon mixing and then at $15 \mathrm{sec}$ intervals for 5.0 min $(n=3-4)$. Plots of $A_{286}$ versus reaction time provided the change in cytosine concentration from $\Delta \mathrm{A}_{286}$ using $\Delta \varepsilon_{286}\left(-0.68 \mathrm{mM}^{-1} \mathrm{~cm}^{-1}\right)$. Specific activities were calculated as: $U=\frac{\left[\Delta C_{\text {substrate }}\right][V]}{[T]\left[W_{\text {enzyme }}\right]}$ (equation 1), where $U$ is $\mu \mathrm{mol} / \mathrm{min} / \mathrm{mg},\left[\Delta \mathrm{C}_{\text {substrate }}\right]$ is the change in cystosine concentration (mM), [V] is volume $(\mathrm{mL}),[\mathrm{T}]$ is the reaction time $(\mathrm{min})$, and $\left[\mathrm{W}_{\text {enzyme }}\right]$ is the total enzyme concentration $(\mathrm{mg})$.

Determination of specific activities with 5-FC as substrate were obtained in a similar manner. Enzymes were added to a solution of $9.6 \mathrm{mM} 5$-FC prepared in $50 \mathrm{mM}$ Tris- $\mathrm{HCl} \mathrm{pH} 7.5$ at $25{ }^{\circ} \mathrm{C}$. Immediately after the addition of enzyme an aliquot $(50 \mu \mathrm{L})$ of the reaction was removed and for every $90 \mathrm{sec}$ there after for $15 \mathrm{~min}(\mathrm{n}=3-4)$. Each aliquot was immediately quenched in $1.95 \mathrm{ml} 0.1 \mathrm{M} \mathrm{HCl}$. Plots were obtained as described above and the amount of 5-FC metabolized was calculated from the $\Delta \mathrm{A}_{297}$ using $\Delta \varepsilon_{297}\left(-0.41 \mathrm{mM}^{-1} \mathrm{~cm}^{-1}\right)$. Specific activities were then calculated using equation 1.

\section{Cytotoxicity Studies}

Cell culture condition. The highly invasive human mammary epithelial cell (HMEC), MDA-MB-231 was originally isolated from pleural effusions of patients with breast cancer, and maintained in RPMI-1640 medium (Invitrogen) supplemented with 10\% fetal bovine serum, 100 units $/ \mathrm{mL}$ penicillin, and $100 \mathrm{~g} / \mathrm{mL}$ streptomycin (Invitrogen, Carlsbad, CA). The MDA-MB-231 cells were grown as monolayers in $75 \mathrm{~cm}^{2}$ culture flasks under a humidified atmosphere of $5 \% \mathrm{CO}_{2}$ in air at $37{ }^{\circ} \mathrm{C}$, and were harvested when they reached $80 \%$ confluence to maintain exponential growth. 
MTT cell proliferation assay. The MTT cell proliferation assay determines the ability of viable cells to reduce the yellow tetrazolium salt [3-(4,5-dimethylthiazol-2-yl)-2,5-diphenyltetrazolium bromide] (MTT) to blue-colored formazan crystals by mitochondrial enzymes. The concentration of formazan crystals can be spectrophotometrically determined when dissolved in an organic solvent. A cell monolayer in exponential growth was harvested using $0.25 \%$ trypsin, and a single-cell suspension was obtained. Cells were counted using a hemocytometer and a light microscope (OLYMPUS BH-2). Cell numbers of MDAMB-231 cells were optimized to remain in exponential growth phase throughout the entire duration of an MTT assay experiment. To this end, single cell suspensions of MDA-MB-231 containing cell densities from $5 \times 10^{2}$ to $1 \times 10^{6}$ cells/well in $100 \mu \mathrm{L}$ of cell culture medium were added to 96 -well plates by serial dilutions. Eight replicates for each cell density were prepared under the same condition. Following attachment of the cells, plates were incubated for 5 days at $37{ }^{\circ} \mathrm{C}$ in $5 \% \mathrm{CO}_{2}$. Cell culture media were exchanged for $100 \mu \mathrm{L} /$ well of phenol red free medium, $10 \mu \mathrm{L}$ of MTT (ATCC, Manassas, VA) was added to each well, and the plate was incubated for $3-4 \mathrm{~h}$ at at $37{ }^{\circ} \mathrm{C}$ in $5 \% \mathrm{CO}_{2}$. Clearly visible purple precipitate from formazan crystals was solubilized using $100 \mu \mathrm{L}$ of detergent reagent (ATCC, Manassas, VA). The 96-well plates were kept dark overnight at room temperature, and an absorbance microplate reader (OPSYS MR, Dynex tech. West Sussex, UK) was used to detect the absorbance in each well at 570 $\mathrm{nm}$ and $650 \mathrm{~nm}$. The average values from the eight replicates were determined. The absorbance at $570 \mathrm{~nm}$ with the absorbance at $690 \mathrm{~nm}$ subtracted to account for the placstic well and cellular debris was plotted against the number of cells/mL to help chose the starting cell density within the linear portion of the plot and the absorbance in the range of $0.75-1.25$. Starting cell number was optimal at $4.0 \times 10^{3}$ cells $/$ well for MDA-MB-231 as determined from the linear correlation between the number of seeded cells and the optical density (OD) values. 
MTT assay on the MDA-MB-231 cell line was used to measure the cytotoxicity of bCD-PLL at the concentration that will be used in in vivo studies $\left(1.5 \mathrm{mg} / \mathrm{mL}, 4.3 \mathrm{uM}\right.$, corresponding to $\left.60 \mathrm{uM} \mathrm{Gd}^{3+}\right)$. Meanwhile, cytotoxicity of bCD and PLL were also tested at their identical molar concentration in bCDPLL. Briefly, after the attachment of the cells, culture media containing bCD, bCD-PLL and PLL, which had been sterile filtered through MILLEX ${ }^{\circledR}$-HV $0.45 \mu \mathrm{m}$ syringe filter were added. These 96-well plates were then incubated for 5 days at $37^{\circ} \mathrm{C}$ in a humidified atmosphere of $5 \% \mathrm{CO}_{2}$. Incubation media were then removed, and the cells were washed to remove the residual compounds. $100 \mu \mathrm{L}$ of fresh phenol-red free RPMI media and $10 \mu \mathrm{L}$ MTT solution were added to each well. Following 4 hours incubation, $100 \mu \mathrm{L}$ of detergent reagent was added, and the plates were placed in the dark at r.t. for overnight. The absorbances were measured as described above. Experimental results are expressed as \% of control and represent the relative cell viability $\left(V_{\mathrm{a}}\right)$ relative to the control, which contained none of the above compounds. $V_{\mathrm{a}}$ was calculated according to equation 2 :

$$
V_{a}=\frac{A_{s-570}-A_{s-650}}{A_{o-570}-A_{o-650}} \times 100 \% \quad \text { Equation } 2
$$

In equation $2, A_{s}$ represents the absorbance value obtained for a sample containing cells in the presence of a given concentration of dye. $A_{o}$ represents the absorbance value corresponding to a well with cells that were incubated without the dye. The relative cell viabilities are presented as means $\pm \mathrm{SD}$ from eight replicated wells.

\section{Cellular uptake of bCD-PLL in vitro}

MDA-MB-231 cells were seeded on Lab-Tek ${ }^{\circledR}$ II glass chamber slides $(75,000$ cells/chamber, Nalge Nunc, Naperville, IL) which were pre-treated with poly-D-lysine $(5 \mu \mathrm{g} / \mathrm{mL})$ for $2 \mathrm{~h}$. After the attachment of the cells, $100 \mathrm{ng} / \mathrm{mL}$ bCD-PLL in RPMI-1640 medium was added and incubated for 0.5, 2, and $4 \mathrm{~h}$ respectively. After the treatment, the cells were washed twice with Hanks, and fixed in fresh prepared 
paraformaldehyde (PFA, 4\%) for 20 min. After washing with Hanks for two times, the cell nuclei were stained with a 1:5000 dilution of DAPI (Invitrogen-Molecular Probes, Eugene, OR) for $5 \mathrm{~min}$ at room temperature. Cell were washed again by PBS for two times, and a cover glass was attached on the slide by using Faramount aqueous mounting medium (Dako, Carpinteria, CA). Microscopy was performed with an Nikon Eclipse 80i motorized upright microscope with epifluorescence and phase contrast optics using $10 \times / 0.3$ or $40 \times / 0.75$ lenses (Nikon USA Inc., Melville, NY) equipped with a Roper Photometrics CoolSnap HQ CCD camera (Photometrics, Tuson, AZ) and IPLab software (Scanalytics BD Biosciences, Rockville, MD). Rhodamine and DAPI fluorescence images were acquired of the same field of view. Rhodamine fluorescence was displayed in red, and DAPI fluorescence was displayed in green, and both fluorescence images were superimposed.

\section{Enzyme Stability in Fresh Mouse Serum}

In order to obtain some indications as to the in vivo stability of bCD-PLL, prior to mouse studies, we investigated the enzymatic activity of bCD-PLL relative to bCD at various times after adding it to fresh mouse serum at $37{ }^{\circ} \mathrm{C}$. bCD or bCD-PLL were added into the fresh mouse serum with final concentrations of 1.56 and $3.08 \mathrm{mg} / \mathrm{mL}$ respectively. At each time point, $2 \mathrm{uL}$ of serum was added immediately to the cuvette with $0.5 \mathrm{mM}$ cytosine, $50 \mathrm{mM}$ Tris- $\mathrm{HCl}, \mathrm{pH}$ 7.5. The $\mathrm{A}_{286}$ was monitored spectrophotometrically, and the specific activities to cytosine were determined by the method described above.

\section{In vitro Enzyme Stability}

As the protocol in the cytoxicity measurement, MDA-MB-231 cells with the cell density of $4.0 \times 10^{3}$ cells/well were seeded to the 96-well plates. After the cells attached, cell culture medium was exchanged 
for phenol red free RPMI medium containing serial dilutions of bCD or bCD-PLL with the same molar concentrations $(4.3,2.15,1.075,0.537,0.268$ and $0.134 \mathrm{uM})$, which had been sterile filtered through MILLEX $^{\circledR}$-HV $0.45 \mu \mathrm{m}$ syringe filter (Millipore Corp. Bedford, MA). After incubation for 0, 2, 8, 24, 48, or $72 \mathrm{hr}$ at $37{ }^{\circ} \mathrm{C}$ in a humidified atmosphere of $5 \% \mathrm{CO}_{2}, 4 \mathrm{uL}$ stock solution of sterilized $5 \mathrm{FC}$ were added, and the final concentration of 5-FC in each well was $1.5 \mathrm{mM}$. After another 5 days' incubation, medium were then removed, and the cells were rinsed by fresh medium. $100 \mu \mathrm{L}$ of fresh phenol-red free RPMI media and $10 \mu \mathrm{L}$ MTT solution were added to each well. After 4 hours incubation, $100 \mu \mathrm{L}$ of detergent reagent was added, and the plates were placed in the dark at r.t. for overnight. The absorbance of each wells were recorded at $570 \mathrm{~nm}$ and using $650 \mathrm{~nm}$ as a reference, and the relative cell viabilities are presented as means $\pm \mathrm{SD}$ from four replicated wells (Figure S8).

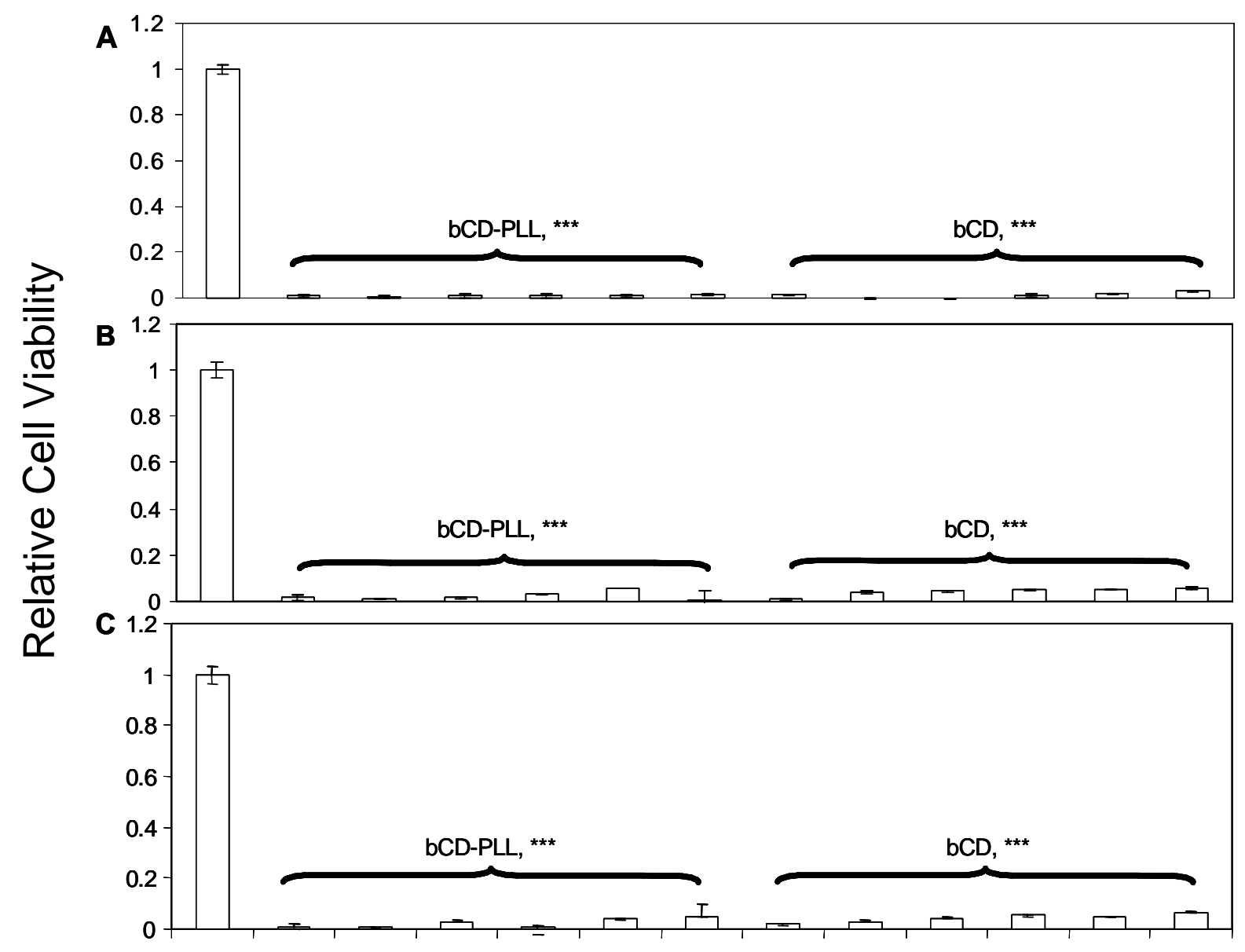




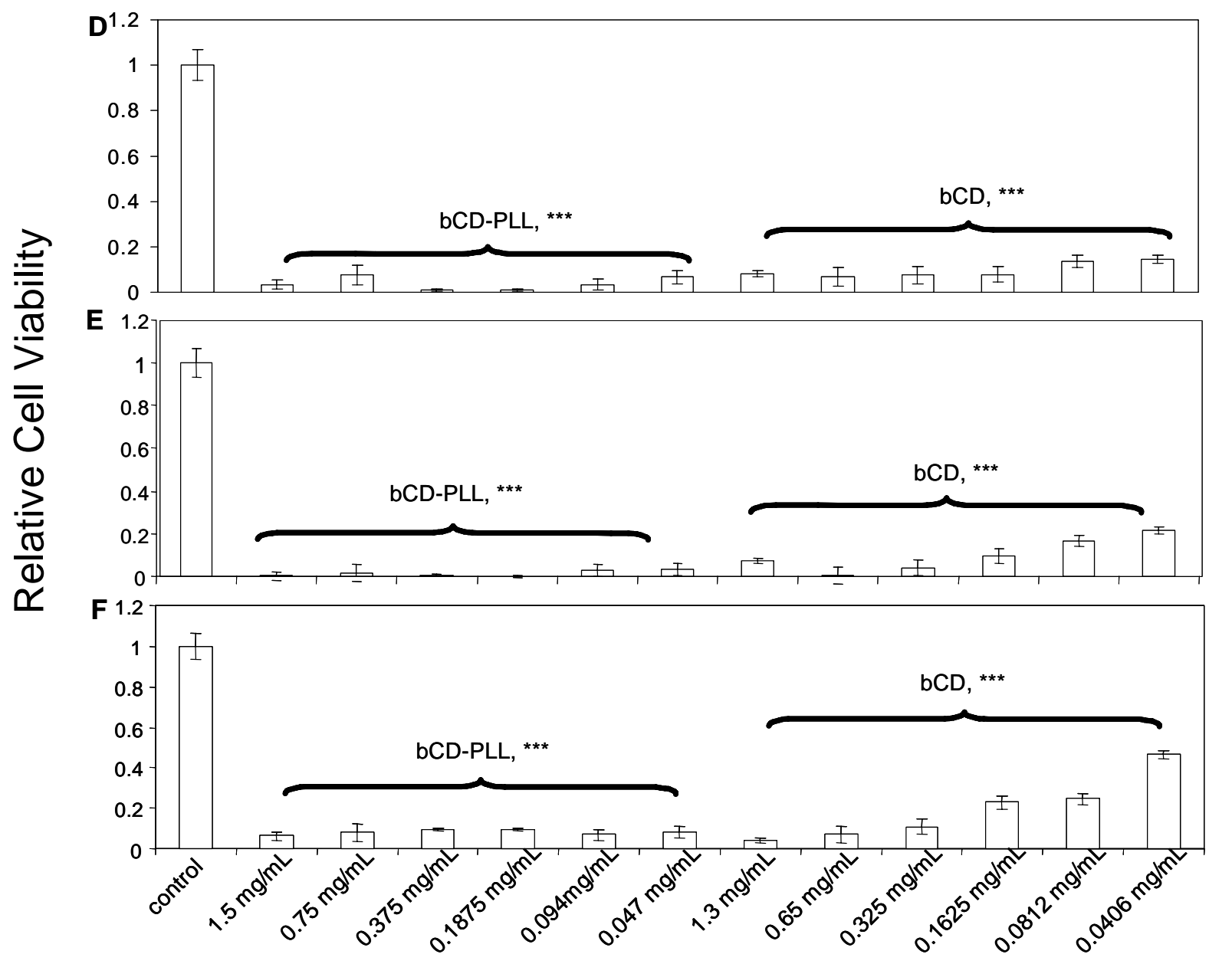

Figure S8. In vitro comparison of the enzymatic stability of bCD-PLL relative to bCD in MDA-MB231 cells. bCD-PLL and bCD were added to cells at concentrations of 4.3, 2.15, 1.075, 0.537, 0.268 and $0.134 \mu \mathrm{M}$. After incubations of $0,2,8,24,48$, and $72 \mathrm{~h}$ (A $-\mathrm{F}$ respectively), 5-FC was added to a final concentration of $1.5 \mathrm{mM}$. The cells were incubated for 5 more days and then assayed for viability. Viabilities were normalized to the control cells. Error bars represent S.D. of the mean $(\mathrm{n}=$ $8)$, *** indicates $\mathrm{P}<0.001$.

\section{References.}

1. Li, C.; Wong, W.-T. Tetrahedron, 2004, 60, 5595-5560.

2. Li, C.; Li, Y.-X.; Law, G.-L.; Man, K.; Wong, W.-T.; Lei, H. Bioconjugate Chem. 2006, 17, in press.

3. Ipata, P. L.; Cercignani, G. Methods Enzymol. 1978, 51, 395-400.

4. Hayden, M. S.; Linsley, P. S.; Wallace, A. R.; Marquardt, H.; Kerr, D. E. Protein Expression Purif. 1998, 12, 173-184. 